\title{
Nutrient Concentrations and Their Seasonal Patterns in Fraser Fir and Norway Spruce Grown in Seven Vegetation Management Programs
}

\author{
Stuart L. Warren, C. Ray Campbell, and Walter A. Skroch \\ Department of Horticultural Science, North Carolina State University, Raleigh, NC 27695-7609 \\ Additional index words. soil management, plant tissue analysis
}

\begin{abstract}
Fraser fir [Abies fraseri (Pursh) Poir.] and Norway spruce [Picea abies (L.) Karst.] were grown in seven vegetation management programs ranging from $100 \%$ cover of grass-dominated vegetation to bare soil on opposing north and south aspects. Concentrations of 13 nutrients were determined at three growth stages during 2 years: active terminal growth, cessation of terminal expansion, and dormancy. Aspect did not affect nutrient concentrations. Vegetation management programs bad a significant impact on nutrient concentration for both species. Nitrogen, Ca, $\mathrm{B}, \mathrm{Fe}$, and Mn concentrations during dormancy were negatively correlated with herbaceous biomass. In contrast, $\mathbf{N}$ during active growth and $\mathrm{P}$ and $\mathrm{Mg}$ concentrations during all stages were positively correlated with herbaceous biomass. Vegetation management only affected the seasonal trend of Mo. Seasonal trends varied by nutrient in both species.
\end{abstract}

Vegetation management programs (VMP), defined as the chemical or mechanical manipulation of herbaceous vegetation occupying the plantation floor, affect the nutritional status of trees by influencing such factors as temperature, soil physical properties, water and nutrient availability, and nutrient losses (Haynes, 1980; Skroch and Shribbs, 1985; Warren et al., 1987b). Many VMP, ranging from bare soil to grass sod, are used in perennial cropping systems (Haynes, 1980).

Most knowledge on the influence of VMP on nutrient concentrations in woody species has been derived from studies that involve bare soil (Skroch et al., 1986) or $100 \%$ grass cover (Thompson, 1984). Foliar macronutrient concentrations in trees grown in a grass sod have increased (Haynes, 1980; Skroch et al., 1986), decreased (Haynes, 1980; Skroch et al., 1986), and remain unchanged (Carter and Miller, 1984), compared to concentrations in trees grown in bare soil. Information on the effect of VMP on micronutrient concentrations is limited (Neilsen and Hogue, 1985). In addition, little is known concerning the nutritional response of woody species to VMP that are intermediate between bare soil and 100\% vegetation cover (Nambiar and Zeal, 1980). Because there are no standards for VMP in woody crop production, a better understanding of how varying VMP affects nutrient concentrations is needed.

Nitrogen, $\mathrm{P}$, and $\mathrm{K}$ concentrations follow similar seasonal patterns in loblolly pine (Pinus taeda L.); maximum concentrations occur in early spring and are followed by a gradual decline during the growing season and an increase during dormancy (Miller, 1966). In Douglas fir [Pseudotsuga menziesii (Mirb.) Franco], $\mathrm{N}$ and $\mathrm{P}$ are highest during active growth, decline in late summer, and remain relatively constant until early spring; $\mathrm{Ca}, \mathrm{Mg}, \mathrm{Fe}$, and $\mathrm{Mn}$ were lowest during active growth and

Received for publication 29 Aug. 1988. Paper no. 11746 of the Journal Series of the North Carolina Agricultural Research Service, Raleigh, NC 27695-7643. We gratefully acknowledge the financial support of the H. Smith-Richardson Foundation and the technical assistance of Kathleen Whitfield and Robbie Wooten. The use of trade names in this publication does not imply endorsement by the North Carolina Agricultural Research Service or the North Carolina Dept. of Agriculture of the products named, nor criticism of similar ones not mentioned. The cost of publishing this paper was defrayed in part by the payment of page charges. Under postal regulations, this paper therefore must be hereby marked advertisement solely to indicate this fact.

'Chief Agronomist, Plant tissue/Waste/Solution Advisory Section, Agronomic Division, North Carolina Dept. of Agriculture, Raleigh, N.C. increased during dormancy; $\mathrm{K}, \mathrm{Cu}, \mathrm{B}$, and $\mathrm{Zn}$ did not follow consistent trends (Proebsting and Chaplin, 1983). However, results from most studies involving VMP are based on annual samples (Fales and Wakefield, 1981; Skroch et al., 1986), so little is known concerning the effects of VMP on seasonal trends.

Warren et al. (1987a, 1987b) reported significant differences in growth of Fraser fir and Norway spruce, herbaceous biomass production and nutrient content, and soil nutrient availability with differing VMP. However, there is no information concerning the nutritional response of Fraser fir and Norway spruce to VMP. This paper examines the influence of VMP on nutrient concentrations in these species. Seven VMP that incorporated various degrees of bare soil, grasses, and broadleaves were created on opposing north and south aspects to address the following objectives: a) to quantify the influence of vegetation management on nutrient concentrations in Fraser fir and Norway spruce, and b) to determine the influence of aspect on these responses.

\section{Materials and Methods}

Descriptions of the study site, experimental design, and vegetation management programs were reported in Warren et al. (1987a). They will be briefly repeated here for clarity.

Study sites. These were located on a north aspect $\left(20^{\circ}\right.$ azimuth, $11 \%$ slope) and a south aspect (220 azimuth, $14 \%$ slope $)$ in Watauga Co., N. C., at an elevation of $1400 \mathrm{~m}$. The soil is a Porter loam (coarse-loamy, mixed, mesic Umbric Dystrochrepts) derived from residuum of dark gneiss. Based on soil tests, $1120 \mathrm{~kg} \cdot \mathrm{ha}^{-1}$ of P $(0 \mathrm{~N}-19 \mathrm{P}-0 \mathrm{~K})$ and Ca (20Ca) (J. Shelton, personal communication) were broadcast over the entire site in Aug. 1982.

Experimental design. The experiment was a randomized complete block design with four blocks of seven treatments on each slope. Each plot, $9 \mathrm{~m} \times 12 \mathrm{~m}$, was divided into five rows (1 $\mathrm{m} \times 9 \mathrm{~m}$ ) with one of five species, Canadian hemlock, Fraser fir, mountain laurel (Kalmia latifolia L.), Norway spruce, and Rhododendron maximum L., randomly assigned to each row. In Spring 1983, nine plants of each species were hand-planted at $0.70-\mathrm{m}$ intervals in rows $2 \mathrm{~m}$ apart. The seedlings were planted at one-half the normal in-row spacing to allow plants to be harvested throughout the study. All plots were separated by two border rows of Fraser fir, $1.5 \mathrm{~m}$ within rows, spaced $2 \mathrm{~m}$ apart. 
Survival of Canadian hemlock was poor due to improper storage of planting stock. Mountain laurel and Rhododendron maximum survival was $\approx 50 \%$, due to the below-average rainfall in 1983 Thus, this report presents results only for Fraser fir and Norway spruce.

The following fertilizers were applied to the soil surface surrounding each tree $\left(0.70 \mathrm{~m}^{2}\right)$, as suggested by Shelton and Huxster (1983): June 1983, diammonium phosphate $(18 \mathrm{~N}-20 \mathrm{P}-0 \mathrm{~K})$ at the rate of $14 \mathrm{~g} \mathrm{~N} /$ tree and before budbreak in 1984 and 1985; potassium nitrate $(14 \mathrm{~N}-0 \mathrm{P}-37 \mathrm{~K}), 18 \mathrm{~g} \mathrm{~N} /$ tree; and ammonium nitrate $(34 \mathrm{~N}-0 \mathrm{P}-0 \mathrm{~K}), 28 \mathrm{~g} \mathrm{~N} /$ tree, respectively.

Vegetation management programs. In Aug. 1982, seven VMP were created (Table 1). Because all VMP were maintained on a row and interrow basis, acronyms were chosen to identify the row and interrow treatment in each VMP. Each acronym contains an R (row) and I (interrow). The letters immediately following the $\mathrm{R}$ and $\mathrm{I}$ indicate the treatment. The treatments were broken down into four areas: B (bare soil), F (forb vegetation), $\mathrm{N}$ (grass-dominated vegetation), and SC \{spring application of [N-(phosphonomethyl) glycine] (glyphosate) . For example, RBIN represents bare soil in the row and grass-dominated vegetation in the interrow.

For the VMP in which the row and interrow were treated differently (RBISC, RBIF, RBIN, RSCIN), both were maintained at a width of $1 \mathrm{~m}$. Herbicides were applied as needed to maintain the outlined VMP on a continuous basis, except for the interrow of RBISC and row of RSCIN, where vegetative regrowth was allowed after the application of glyphosate around 15 May 1983, 1984, and 1985. Plots were never mowed. Total vegetation control was maintained with glyphosate. ( \pm )-2-[4[[5-(trifluoromethyl)-2-pyridinyl]oxy] phenoxy] propanoic acid (fluazifop) was used to control grasses. Herbicides were never applied to test plants.

Foliar samples. For nutrient analysis in 1984 and 1985, current season's lateral branch foliage was collected from each species. Samples were taken from two randomly selected trees in each plot (total of eight trees/VMP per aspect). The trees on the ends of the rows in each plot were excluded from sampling. Samples were collected from the two uppermost whorls for Fraser fir and from the upper third of the tree for Norway spruce. The samples were collected at three growth stages: a) active terminal expansion (June), b) cessation of terminal expansion (August), and c) dormancy (December) (also referred to as time 1, time 2 , and time 3, respectively). Samples were dried at $70 \mathrm{C}$ for 72 $\mathrm{hr}$ and ground to pass through a 1-mm-mesh sieve.

Nutrient analysis was performed by the North Carolina Dept. of Agriculture, Agronomic Division, Raleigh (Tucker, 1974). Total $\mathrm{N}$ was determined by a Kjeldahl method (Bremner et al., 1964; Schuman et al., 1973). Phosphorus was determined using the ammonium molybdate-ascorbic acid calorimetric method (Watanabe et al., 1962). Potassium, Ca, Mg, Cu, Fe, Mn, Na, and $\mathrm{Zn}$ were determined by atomic absorption spectrophotometry using lanthanum and lithium agents to prevent interferences from other ions. Sulfur was determined turbidimetrically with a barium acetate-glacial acetic acid solution ( $255 \mathrm{~g}$ barium acetate, $100 \mathrm{ml}$ glacial acetic acid, $1 \mathrm{~g}$ polyvinyl pyrolidine in 1 liter of distilled water); B by a modified curcumin method (Grinstead et al., 1967); Mo spectrophotometrically (Haddad et al., 1974).

Statistical analysis. All variables were tested for differences using analysis of variance with means separated by the WallerDuncan Bayesian method (SAS Institute, Cary, N.C.). Reported correlations were significant at $P<0.05$.

\section{Results and Discussion}

Aspect did not affect nutrient concentrations in Fraser fir or Norway spruce (data not shown). Furthermore, there were no significant interactions with aspect; thus, the data for each nutrient were pooled over aspect for statistical analysis.

Nutrient concentrations were not significantly different in Fraser fir or Norway spruce when the trees were grown in a 1-m-wide, vegetation-free row, regardless of the vegetation occupying the interrow [annual forbs (RBISC), perennial forbs (RNIF), or perennial grasses (RBIN)] (data not shown). Thus, nutrient con-

Table 1. Vegetation management programs and the resulting major growth form and percent cover occupying the row and interrow.

\begin{tabular}{|c|c|c|c|c|c|}
\hline \multicolumn{4}{|c|}{ Vegetation management programs } & \multirow{2}{*}{$\begin{array}{l}\text { Growth } \\
\text { form }^{2}\end{array}$} & \multirow{2}{*}{$\begin{array}{c}\text { Cover } \\
(\%)^{y}\end{array}$} \\
\hline & Row & Interrow & Vegetation control & & \\
\hline \multirow[t]{2}{*}{ RBIB } & Bare & Bare & Continuous control in row ${ }^{x}$ & ... & 0 \\
\hline & & & Continuous control in interrow & -.- & c \\
\hline \multirow[t]{2}{*}{ RBISC } & Bare & $\mathrm{SC}^{\mathrm{w}}$ & Continuous control in row & $\cdots$ & c \\
\hline & & & Spring application in interrow & $\mathrm{F}$ & $0-100$ \\
\hline \multirow[t]{2}{*}{ RBIF } & Bare & Forbs & Continuous control in row & $\cdots$ & c \\
\hline & & & Control of grasses in interrow ${ }^{v}$ & $\mathrm{~F}$ & 100 \\
\hline \multirow[t]{2}{*}{ RBIN } & Bare & Native & Continuous control in row & $\cdots$ & c \\
\hline & & & No chemical treatment in interrow & G & 100 \\
\hline \multirow[t]{2}{*}{ RSCIN } & $\mathrm{SC}$ & Native & Spring application in row & $\mathrm{F}$ & $0-100$ \\
\hline & & & No chemical treatment in interrow & $\mathrm{G}$ & 100 \\
\hline \multirow[t]{2}{*}{ RFIF } & Forbs & Forbs & Control of grasses in row & $\mathrm{F}$ & 100 \\
\hline & & & Control of grasses in interrow & $\mathrm{F}$ & 100 \\
\hline \multirow[t]{2}{*}{ RNIN } & Native & Native & No chemical treatment in row & G & 100 \\
\hline & & & No chemical treatment in interrow & G & 100 \\
\hline
\end{tabular}

${ }^{2}$ Vegetation was divided into two major growth forms: $G=$ grass-dominated and $F=$ forbs (broadleaf). Dashes indicate no vegetation (bare soil).

"Percentage of soil surface covered by vegetation.

${ }^{x}$ Glyphosate applied at the rate of $0.56 \mathrm{~kg}$ a.i./ha.

${ }^{w} \mathrm{SC}=$ spring control.

vFluazifop applied at the rate of $0.56 \mathrm{~kg}$ a.i./ha. 
centrations from RBIN will be given as representative of RBISC and RBIF. There were no significant differences in nutrient concentrations between RFIF and RNIN in either species. Therefore, RNIN will be given as representative of RFIF. In addition, RBIB and RBIN were not significantly different for every nutrient. Consequently, only RBIB, RSCIN, and RNIN are shown in all figures. RBIN is shown only when it was significantly different from RBIB.

\section{Fraser fir}

Concentrations of all nutrients except $\mathrm{Na}$ varied significantly $(P<0.01)$ with stage of growth. Vegetation management program significantly affected all nutrient concentrations except $\mathrm{K}$, $\mathrm{Cu}, \mathrm{Mo}, \mathrm{Na}$, and $\mathrm{Zn}$ (data not shown). These results were consistent over both years.

Nitrogen concentration displayed similar trends in all VMPincreasing concentration from active growth to dormancy (Fig. 1A). Fife and Nambiar (1982) and Miller (1984) have suggested that increased $\mathrm{N}$ levels during dormancy represent $\mathrm{N}$ storage rather than luxury consumption. This trend differs from Douglas fir, where $\mathrm{N}$ decreased throughout the growing season (Proebsting and Chaplin, 1983). Significant differences at times 1 and 2 varied by year (Fig. 1A). Vegetation management programs affected $\mathrm{N}$ concentration at time 3 in both years (Fig. 1A), with concentration positively correlated $(r=0.77)$ with herbaceous biomass (Warren et al., 1987a). Nitrogen levels were higher for RBIB than RBIN at time 3. This difference suggests that either the roots from the interrow vegetation in RBIN had exploited the open soil beneath the bare row and were competing with

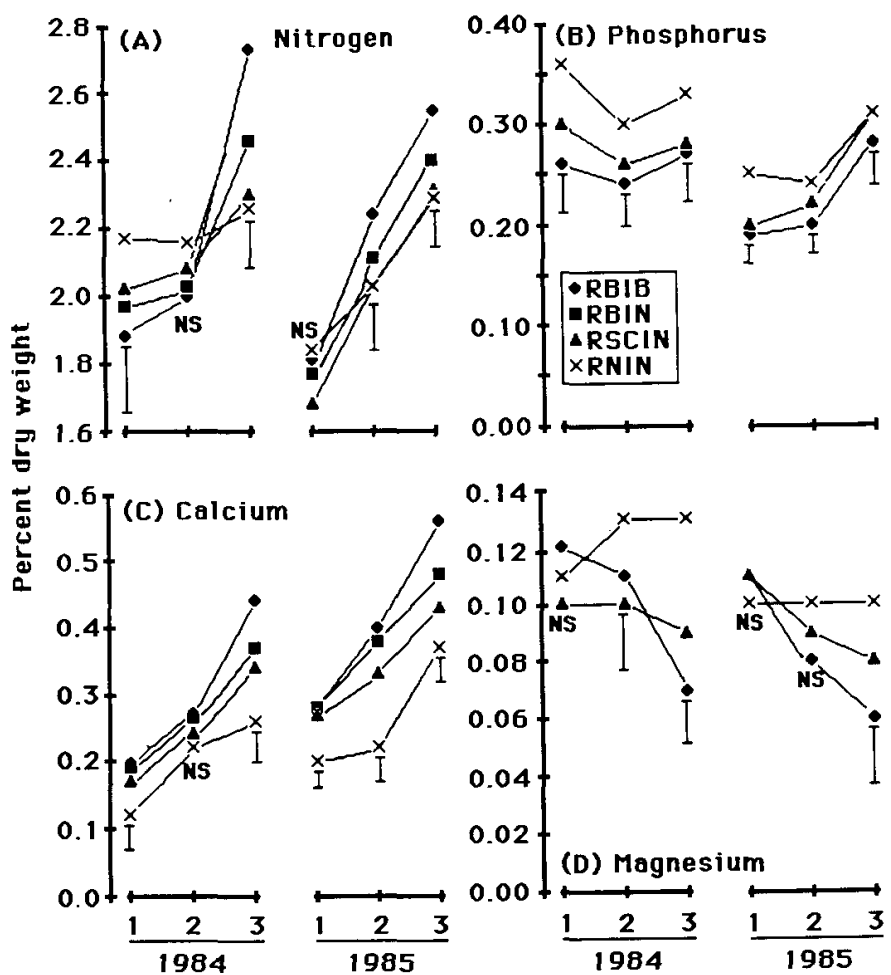

Fig. 1. Influence of vegetation management programs on foliar concentration of $\mathrm{N}(\mathbf{A}), \mathrm{P}(\mathbf{B}), \mathrm{Ca}(\mathbf{C})$, and $\mathrm{Mg}(\mathbf{D})$ during terminal expansion 1), cessation of terminal expansion (2), and dormancy (3) in Fraser fir. Vertical bars represent minimum significant differences determined by the Waller-Duncan test with k-ratio $=100$.

${ }^{\text {NSNonsignificant. }}$ the trees for $\mathrm{N}$ or the tree roots were limited to the bare area defined by the row, which could limit $\mathrm{N}$ uptake. Roots excavated in 1985 suggested that Fraser fir roots are confined to the row when a vegetative cover is present in the interrow (Warren et al., 1987a). This result supports Atkinson's (1980) hypothesis that VMP that consist of a bare row and a vegetative cover in the interrow can influence crop growth by limiting the exploitation of soil to the bare area defined by the row. With bare soil, the crop is only limited by intraspecific competition.

Trees grown in RNIN generally had a high level of $\mathrm{N}$ at time 1 and a lower level at time 3 than those in the other treatments, which suggests that $\mathrm{N}$ uptake and retranslocation were not keeping up with growth. This decrease was presumably due to $\mathrm{N}$ competition by the grass cover. Grasses are considered extremely efficient scavengers of $\mathrm{N}$, and can absorb all the mineral $\mathrm{N}$ within a given volume of soil (Warren et al., 1987b). Conversely, RBIB was lowest in N concentration at time 1 and the highest at time 3 . The standard recommendation for conifers is to sample current-year foliage during dormancy (Lavender, 1970). However, van den Driessche (1974) postulated that analyses made in the dormant season do not give a good indication of nutrient availability during active growth. He suggested that foliar samples be taken at the period of maximum "nutrient stress", probably when growth extension is complete. Data herein support this hypothesis.

Phosphorus exhibited a nonlinear trend in 1984, with the lowest concentration at time 2 (Fig. 1B). Trees grown in RNIN were the only VMP to exhibit a similar trend in 1985. Phosphorus was highest during active growth (time 1) in Douglas fir Christmas trees (Proebsting and Chaplin, 1983). Among VMP, $\mathrm{P}$ levels were consistently highest in RNIN, but differences were not always significant. Phosphorus levels were lowest in RBIB (Fig. 1B). Increased foliar P concentration in sod, compared to bare soil, has been reported in apples (Malus spp.) (Neilsen and Hogue, 1985) and white pine (Pinus strobus L.) (Skroch et al., 1986). Several authors have hypothesized that a grass cover mobilizes $\mathrm{P}$ and increases its availability to the tree, which results in increased P levels (Bould et al., 1972; Neilsen and Hogue, 1985). The decrease between time 1 and 2 in 1984 suggests that retranslocation and P uptake were not able to keep up with the growth in any of the VMP. Similar to N, increased $\mathrm{P}$ levels at time 3 are assumed to reflect storage. These results are similar to those reported by Neilsen and Hogue (1985). However, Nambiar and Zed (1980) reported that P concentration in radiata pine ( $P$. radiata $D$. Don) was not affected by various densities of weed populations.

Calcium displayed similar trends in all VMP; increasing concentration from active growth until dormancy (Fig. 1C). A similar trend was reported by Proebsting and Chaplin (1983) for Douglas fir. At time 3, the relative order of $\mathrm{Ca}$ concentration among VMP was identical to that reported previously for stem diameter (Warren et al., 1987a). Similar to N, Ca levels for RBIB were significantly greater than those for RBIN at time 3. Levels for RSCIN fluctuated between RBIB and those for RNIN, which might be explained by changes in the soil fertility environment in RSCIN during the growing season. Early in the season, the soil fertility levels of RBIB and RSCIN were similar. However, by the end of the growing season the soil fertility levels of RSCIN were more closely aligned with RNIN (Warren et al., 1987b). This emphasizes that needles rapidly reflect changes in nutrient supply.

Calcium uptake depends on young root tips in which the cell walls of the endodermis are still unsuberized (Clarkson and 
Sanderson, 1969). In addition, current evidence suggests that $\mathrm{Ca}$ is retranslocated only to a very limited degree in the shoot (Mingel and Kirkby, 1982). Thus, Ca concentration should reflect root growth. This is supported by a strong correlation ( $\mathrm{r}$ $=0.71$ ) between $\mathrm{Ca}$ concentration and root dry weight (Warren, 1986).

With the exception of RNIN, Mg concentration decreased from time 1 to 3 (Fig. ID). At time 3, Mg levels for RBIB were lower than those for RNIN, while the Mg levels of RSCIN were intermediate. Similar to $\mathrm{P}$, increased levels of $\mathrm{Mg}$ in RNIN suggest that RNIN affected growth more than uptake. Lower levels of $\mathrm{Mg}$ in RBIB and RSCIN suggested that $\mathrm{Mg}$ uptake was not keeping up with growth. However, a decrease in foliar nutrient concentration does not necessarily imply a reduction in nutrient content per needle (Timmer and Stone, 1978). The recycling of $\mathrm{Mg}$ in RNIN may also have contributed to the increased foliar Mg levels (Warren et al., 1987b).

Sulfur exhibited a nonlinear trend in each VMP in 1984 with the highest concentration at time 2 (Fig. 2A). Nutrient concentration in RNIN was the only VMP that had a similar trend in 1985. At all three sample times in 1984, S concentration decreased with increasing herbaceous cover: RBIB > RSCIN > RNIN (Warren et al., 1987b). The increase between time 1 and 2 in 1984 suggests that $S$ uptake was greater than needed for growth in all the VMP. Similar to $\mathrm{Ca}$, changes in soil fertility in RSCIN during the growing season may explain the shift of RSCIN (Warren, 1986). In 1985, S levels did not respond to VMP.

Boron followed a nonlinear trend in 1985, with the lowest levels at time 2 (Fig. 2B). Tissue quantities during active growth were not adequate for B analysis in 1984. Similar to $\mathrm{N}$ and $\mathrm{Ca}$,

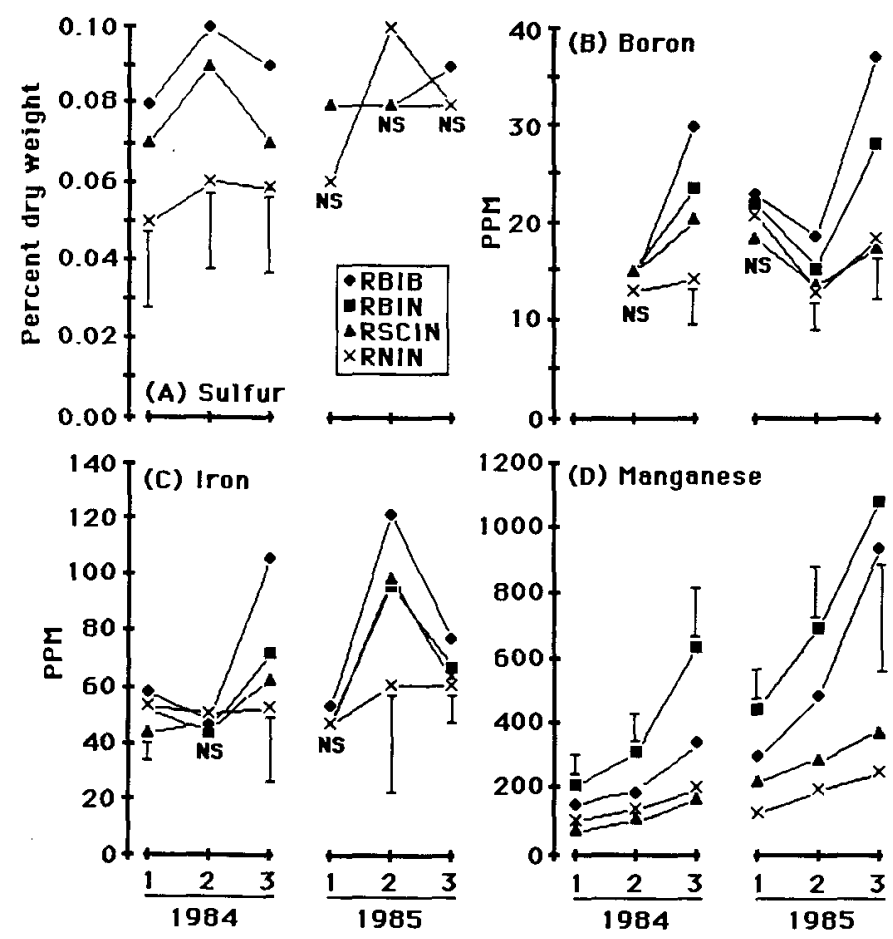

Fig. 2. Influence of vegetation management programs on foliar concentration of S (A), B (B), Fe (C), and Mn (D) during terminal expansion (1), cessation of terminal expansion (2), and dormancy (3) in Fraser fir. Vertical bars represent minimum significant differences determined by the Waller-Duncan test with k-ratio $=100$. ${ }^{\text {NSNonsignificant. }}$ the $B$ data indicate that the interrow vegetation (RBIN) influenced B uptake as RBIN was significantly lower than RBIB at time 3. Root competition, which is not visually obvious, could play a critical role in determining if a bare row, combined with a forb or grass interrow, will be adequate to maintain maximum growth (Warren et al., 1987a). Foliar analysis could be a useful tool to alert the grower that the VMP may not be adequate to assure maximum growth. Boron levels in RSCIN were greater than RNIN at time 3 in 1984, but not in 1985. Decreasing B concentration between times 1 and 2 may indicate that B uptake was not keeping up with growth, particularly since B is relatively immobile in the phloem (Tiffin, 1972).

Trends were similar for Fe among all VMP within each year (Fig. 2C). However, Fe concentrations at time 2 differed between 1984 and 1985 for all VMP except RNIN. The application of $\mathrm{KNO}_{3}$ in 1984 may have suppressed $\mathrm{Fe}$ uptake at time 2, since the uptake of $\mathrm{Fe}$ and $\mathrm{K}$ is competitive (Lingle et al., 1963). In general, increasing cover tended to decrease the Fe concentration, but analysis must be conducted in additional years before any conclusions can be finalized.

Manganese responded similarly to $\mathrm{Ca}$, with a linear increase in all VMP over time (Fig. 1D). This increase suggests that Mn uptake was greater than needed for growth in all the VMP. The smallest shift in Mn levels occurred in RNIN. The relative order of RBIN > RBIB > RNIN was maintained at all sampling times, even though the differences were not always significant. In contrast, Neilsen and Hogue (1985) reported that Mn in apples was not responsive to VMP. Manganese was different from all other elements in that RBIN was greater than RBIB.

\section{Norway spruce}

Growth stage significantly $(P<0.01)$ affected all nutrient concentrations. Vegetation management programs significantly affected nutrient concentrations except for $\mathrm{S}, \mathrm{Cu}$, and $\mathrm{Zn}$ (data not shown). Results were consistent over both years. The concentration response to VMP of $\mathrm{N}, \mathrm{P}, \mathrm{Ca}, \mathrm{B}, \mathrm{Mn}, \mathrm{Cu}$, and $\mathrm{Zn}$ and their seasonal trends were similar to those presented for Fraser fir (data not shown).

The $\mathrm{K}$ trend was consistent with each year, but the two years contrasted (Fig. 3A). There was a nonlinear trend in 1984 with the highest percent dry weight at time 2 , while the percent dry weight increased from times 1 to 3 in 1985. The application of $\mathrm{KNO}_{3}$ in 1984 may explain the contrast in trends between years. Proebsting and Chaplin (1983) reported that K concentration in Douglas fir did not follow a trend throughout the year. Concentrations for RNIN were consistently greater than for RBIB. Elevated foliar K concentration for apple (Haynes and Goh, 1980) and radiata pine (Neilsen and Hogue, 1985) maintained in a grass sod, as opposed to bare soil, has been reported. Neilsen and Hogue (1985) suggested that K recycling by the sod cover has produced these results. In addition, O'Carroll (1972) concluded that vegetation did not interfere with the uptake of applied $\mathrm{K}$ by Norway spruce and that vegetation may play a role in retaining applied $\mathrm{K}$ on the site. In this study, RNIN maintained an elevated level of exchangeable soil $\mathrm{K}$ when compared to RBIB (Warren et al., 1987b), presumably by growth and decay of herbage shoots and roots. However, dilution due to growth in RBIB cannot be discounted.

Magnesium concentrations tended to increase linearly from times 1 to 3 (Fig. 3B). In 1984, Mg levels for RNIN showed the strongest deviation. RNIN had a greater percent dry weight than the other VMP (excluding RSCIN) at all times. Similar to $\mathrm{K}$, exchangeable soil $\mathrm{Mg}$ was greater for RNIN compared to 


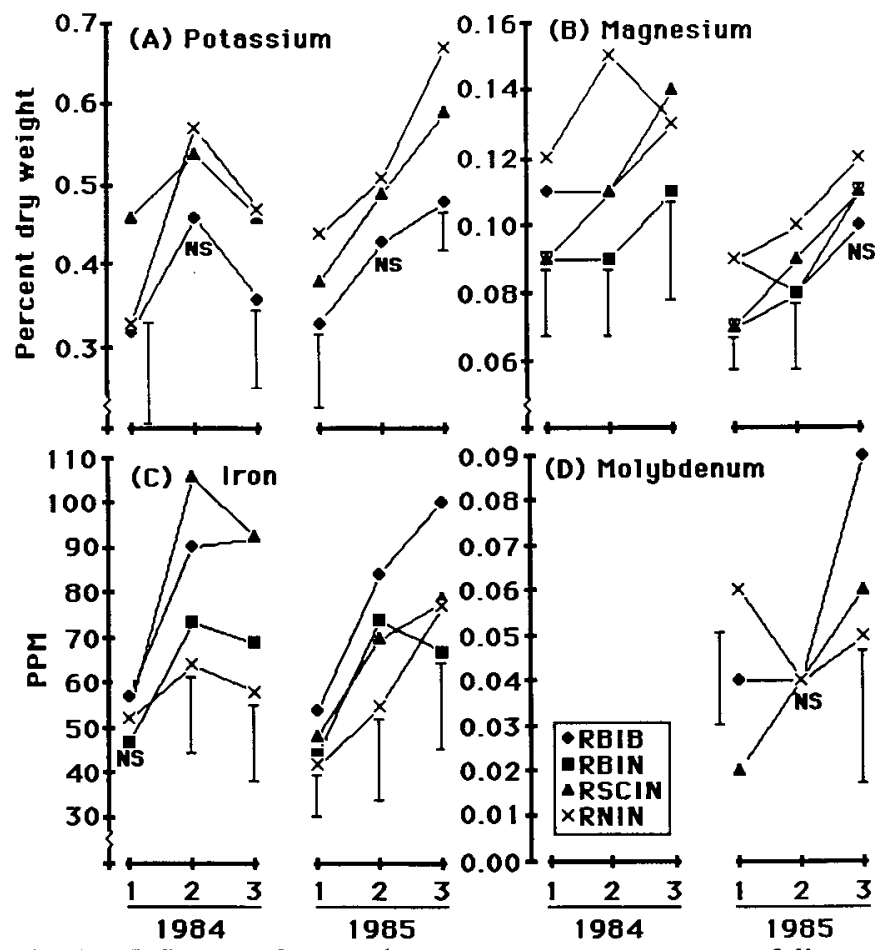

Fig. 3. Influence of vegetation management programs on foliar concentration of $\mathrm{K}(\mathbf{A}), \mathrm{Mg}(\mathbf{B}), \mathrm{Fe}(\mathbf{C})$, and Mo (D) during terminal expansion (1), cessation of terminal expansion (2), and dormancy (3) in Norway spruce. Vertical bars represent minimum significant differences determined by the Waller-Duncan test with $\mathrm{k}$-ratio $=$ 100.

NSNonsignificant.

RBIB (Warren et al., 1987b). Foliar Mg and soil Mg sampled in August (Warren et al., 1987b) were positively correlated in both years, with values ranging from 0.34 to 0.56 , which suggests that the higher Mg level may be due to the elevated soil level. However, it cannot be determined from this study whether the elevated $\mathrm{Mg}$ levels are due to increased soil $\mathrm{Mg}$ availability with subsequent increased uptake or due to growth dilution in RBIB. The overall $\mathrm{Mg}$ response to VMP was not clear.

Within each year, the seasonal trends of Fe were similar in all VMP, but trends contrasted between years (Fig. 3C). The general trend in 1984 was nonlinear with the highest concentrations at time 2. In 1985, Fe concentration increased over time for all VMP, excluding RBIN. Iron levels were consistently greater for RBIB as compared to RBIN. Levels for RSCIN were similar to those for RBIB in 1984 and RNIN in 1985. Currentyear's foliage readily reflects changes in nutrient supply (Miller, 1984). With the many factors affecting nutrient supply (i.e., temperature, water, and nutrient availability), annual fluctuations in nutrient concentrations and trends might be expected (Miller, 1966).

Vegetation management programs affected the seasonal trend of Mo, based on 1985 data. The tissue sample was inadequate for Mo analysis in 1984. Although all VMP had similar values at time 2 (Fig. 3D), there were extreme differences at times 1 and 3. Between times 1 and 2, RBIB changed little; RSCIN increased; and RNIN decreased. The Mo levels in all VMP increased between times 2 and 3. As with N, Mo levels in RBIB were lower than RNIN during active growth and higher during dormancy, which supports van den Driessche's (1974) hypothesis.

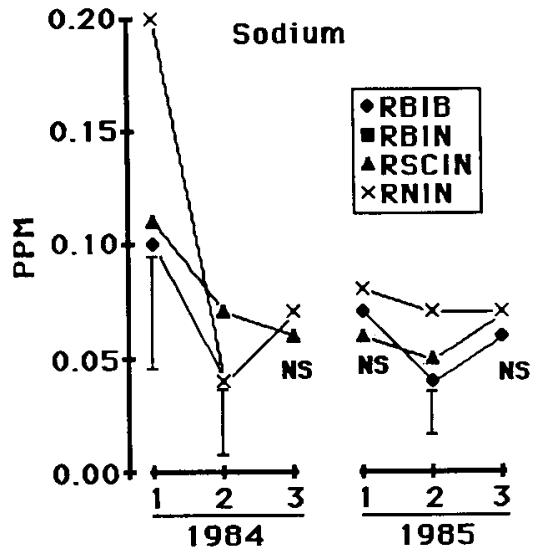

Fig. 4. Influence of vegetation management programs on foliar concentration of $\mathrm{Na}$ during terminal expansion (1), cessation of terminal expansion (2), and dormancy (3) in Norway spruce. Vertical bars of represent minimum significant differences determined by the WallerDuncan test with k-ratio $=100$.

Ns Nonsignificant.

Sodium content showed similar trends in both years (Fig. 4). The major shift in 1984 occurred between times 1 and 2. Only minor changes in $\mathrm{Na}$ levels occurred in 1985. Similar to K, RNIN had the greatest concentration of $\mathrm{Na}$ at all times, excluding time 2 in 1984.

Relationship between assessed variables. Correlations were attempted in 1984 and 1985 between N, P, K, Ca, and Mg concentrations of Fraser fir and Norway spruce and soil $\mathrm{NO}_{3}$, $\mathrm{P}, \mathrm{K}, \mathrm{Ca}$, and $\mathrm{Mg}(0-$ to $15-\mathrm{cm}$ depth) in August (Warren et al., 1987b). In addition, correlations were attempted between all nutrient concentrations in Fraser fir and Norway spruce and herbaceous biomass in May and August. Foliar N at time 3 and soil $\mathrm{NO}_{3}$ were negatively correlated in both species, with values ranging from -0.40 to -0.45 . Foliar $\mathrm{Mg}$ and soil $\mathrm{Mg}$ (Warren et al., 1987b) were positively correlated in both species, with values ranging from 0.34 to 0.56 . No other correlations with soil nutrients were found. Neilsen and Edwards (1982) reported similar results with apples. The lack of significant correlations may be indicative of adequate levels of soil nutrients in all VMP.

Significant negative correlations were detected between herbaceous above-ground biomass in August and $\mathrm{N}, \mathrm{Ca}, \mathrm{B}, \mathrm{Fe}$, and $\mathrm{Mn}$ concentrations at time 3 in both species (Table 2). Negative correlations between herbaceous biomass and stem diameter and root dry weight have been previously reported (Eissenstat and Mitchell, 1982; Warren et al., 1987a). In contrast, $\mathrm{P}$ and $\mathrm{Mg}$ concentrations were positively correlated with herbaceous biomass. The nutrients not affected by $\mathrm{VMP}(\mathrm{Cu}, \mathrm{Zn})$ were not correlated (Table 2). Differences in the tree's functional environment (i.e., soil temperature and water and nutrient availability), which are directly related to the changes in vegetative composition and density produced by the VMP (Atkinson and Herbert, 1979), are responsible for the differences in nutrient concentrations. Consequently, herbaceous biomass may be the best single indicator of the sum of these changes.

The N and Mo data support van den Driessche's (1974) hypothesis that sampling during active growth, rather than during dormancy, would be more informative of nutrient availability. However, data herein provide some evidence that analysis of certain nutrients, notably $\mathrm{Ca}, \mathrm{Mg}, \mathrm{B}$, and $\mathrm{Mn}$, would be of little 
Table 2. Correlation coefficients ${ }^{2}$ averaged over 1984 and 1985 between herbaceous biomass in August in each VMP and nutrien concentration at time 3 (dormancy) in Fraser fir and Norway spruce.

\begin{tabular}{lcc}
\hline \hline & Herbaceous biomass $^{y}$ & \\
\hline Nutrients & Fraser fir & Norway spruce \\
\hline $\mathrm{N}$ & -0.77 & -0.52 \\
$\mathrm{P}$ & 0.53 & 0.63 \\
$\mathrm{~K}$ & $\mathrm{NS}$ & 0.57 \\
$\mathrm{Ca}$ & -0.67 & -0.63 \\
$\mathrm{Mg}$ & 0.64 & 0.40 \\
$\mathrm{~S}$ & -0.56 & $\mathrm{NS}$ \\
$\mathrm{B}$ & -0.77 & -0.73 \\
$\mathrm{Cu}$ & $\mathrm{NS}$ & $\mathrm{NS}$ \\
$\mathrm{Fe}$ & -0.59 & -0.63 \\
$\mathrm{Mn}$ & -0.50 & -0.48 \\
$\mathrm{Na}$ & $\mathrm{NS}$ & $\mathrm{NS}$ \\
$\mathrm{Zn}$ & $\mathrm{NS}$ & $\mathrm{NS}$ \\
$\mathrm{Mo}$ & $\mathrm{NS}$ & -0.62 \\
\hline
\end{tabular}

${ }^{z}$ Coefficients are significant at $P=0.05$ or nonsignificant (NS).

${ }^{y}$ Herbaceous biomass $=$ dry weight of above-ground portions.

value if taken during active growth. Recommendations for sampling time may need to be adjusted for each element.

\section{Literature Cited}

Atkinson, D. 1980. Some observations of the root growth of young apple trees and their uptake of nutrients when grown in herbicide strips in grassed orchards. Plant \& Soil 49:459-471.

Bould, C., H.M. Hughes, and E. Gunn. 1972. Effects of soil management and NPK fertilizers on tree growth, yield and leaf nutrient composition of dessert apples. Expt. Hort. 24:25-26.

Bremner, J.M. and D.R. Kenny. 1964. Steam distillation methods for determination of ammonium, nitrate and nitrite. Anal. Chem. Acts 32:485-495.

Carter, G.A. and J.H. Miller. 1984. Effect of vegetative competition on the moisture and nutrient status of loblolly pine. Can. J. For. Res. 14:1-9.

Clarkson, D.T. and J. Sanderson. 1969. The uptake of a polyvalent cation and its distribution in the root apices of Allium cepa. Tracer and autoradiographic studies. Planta 89:136-154.

Eissenstat, D.M. and J.E. Mitchell. 1983. Effects of seeding grass and clover on growth and water potential of Douglas-fir seedlings. For. Sci. 29:166-179.

Fales, S.L. and R.C. Wakefield. 1981. Effects of turfgrass on the establishment of woody plants. Agron. J. 73:605-610.

Fife, D.N. and E.K.S. Nambiar. 1982. Accumulation and retranslocation of nutrients in developing needles in relation to seasonal growth of young radiata pine trees. Ann. Bot. 50(NS):817-829.

Haddad, P. R., P.W. Alexander, and L.E. Smygthe. 1984. Spectrophotometric and fluorometric determination of traces of molybdenum in soils and plants. Talanta 22:60-69.

Haynes, R.J. 1980. Influence of soil management practice on the orchard agro-ecosystem. Agro-Ecosystem 6:3-32.

Haynes, R.J. and K.M. Goh. 1980. Some effects of orchard soil management on sward composition, levels of available nutrients in the soil and leaf nutrient content of mature 'Golden delicious' apple trees. Scientia Hort. 13:15-25.

Lavender, D.P. 1970. Foliar analysis and how it is used: a review, Oregon State Univ. Res. Note 52.
Lingle, J. C., L.O. Tiffin, and J.C. Brown. 1963. Iron-uptake transport of soybeans as influenced by other cations. Plant Physiol. 38:7176

Mengel, K. and E.A. Kirkby. 1982. Principles of plant nutrition. 3rd. ed. Intl. Potash Institute, Switzerland.

Miller, W.F. 1966. Annual changes in foliar nitrogen, phosphorus, and potassium levels of loblolly pine (Pinus taeda L.) with site and weather factors. Plant \& Soil 24:360-378.

Miller, H.G. 1984. Dynamics of nutrient cycling in plantation ecosystems, p. 53-78. In: G.D. Bowen and E.K.S. Nambiar (eds.). Nutrition of plantation forests. Academic, New York.

Nambiar, E.K.S. and P.G. Zeal. 1980. Influence of weeds on the water potential, nutrient content and growth of young radiata pine. Austral. For. Res. 10:279-288.

Neilsen, G.H. and T. Edwards. 1982. Relationships between Ca, Mg, and $\mathrm{K}$ in soil, leaf and fruits of Okanagan orchards. Can. J. Soil Sci. 62:365-374.

Neilsen, G.H. and E.J. Hogue. 1985. Effect of orchard soil management on the growth and leaf nutrient concentration of young dwarf Red Delicious apple trees. Can. J. Soil Sci. 65:309-315.

O'Carroll, N. 1972. Chemical weed control and its effect on the response to potassium fertilization. Irish For. 29:20-31.

Proebsting, W.M. and M.H. Chaplin. 1983. Elemental content of Douglas-fir shoot tips: sampling and variability. Commun. Soil Sci. Plant Anal. 14:353-362.

Schuman, G. E., M.A. Stanley, and D. Knudson. 1973. Automated total nitrogen analysis of soil and plant samples. Soil Sci. Soc. Amer. Proc. 37(3):480-481.

Shelton, J.E. and W.T. Huxster. 1983. Fertilizing fraser fir christmas trees. North Carolina Agr. Ext. Serv. Christmas Tree Notes CTN010 .

Skroch, W.A. and J.M. Shribbs, 1985. Orchard management: An overview. HortScience 21:390-394.

Skroch, W.A., J.M. Shribbs, R.E. Bir, and J.E. Shelton. 1986. Influence of ten ground cover systems on growth and market value of eastern hemlock and eastern white pine. J. Environ. Hort. 4:116120

Thompson, D.A. 1984. The influence of shelter and weeds on early growth of sitka spruce and lodgepole pine. Forestry 57:1-16.

Tiffin, L.O. 1972. Translocation of micronutrients in plants, p. 199229. In: J.J. Mortvedt, P.M. Giordano, and W.L. Lindsay (eds.). Micronutrients in agriculture. Soil Sci. Soc. Amer., Madison, Wis.

Timmer, V.R. and E.L. Stone. 1978. Comparative foliar analysis of young balsam fir fertilized with nitrogen, phosphorus, potassium and lime. Soil Sci. Soc. Amer. J. 42:125-130.

Tucker, M.R. 1974. A modified heating block for plant tissue digestion. Commun. Soil Sci. Plant Anal. 56:539-546.

van den Driessche, R. 1974. Prediction of mineral nutrient status of trees by foliar analysis. Bet. Rev. 40:347-394.

Warren, S.L. 1986. Plantation management: Its influence on soil fertility, herbaceous vegetation and growth of fraser fir and Norway spruce. PhD Diss., North Carolina State Univ., Raleigh.

Warren, S.L., W.A. Skroch, K.B. Perry, and T.J. Monaco. 1987a. Vegetation management: its influence on survival and early plant growth of fraser fir and Norway spruce. J. Amer. Soc. Hort. Sci. 112:955-962.

Warren, S.L., T.J. Monaco, and W.A. Skroch. 1987b. Effect of vegetation management on soil nutrients and nutrient content of herbaceous vegetation, J. Amer. Soc. Hort. Sci. 112:962-968.

Watanabe, F.S. and S.R. Olsen. 1962. Calorimetric determination of phosphorus in water extracts of soil. Soil Sci. 93:532-533. 